Original Research

\title{
Antinociceptive, Antipyretic and Anti-inflammatory Activities of Natural Betaine
}

\author{
Yasmin Abouelbaqa ${ }^{1 *}$, Hossny El banna ${ }^{2}$, Mohamed Eldakroury ${ }^{1}$, and Ehab Abdelhiee ${ }^{3}$
}

\begin{abstract}
1 Department of Pharmacology, Faculty of Veterinary Medicine, Matrouh University, Matrouh, Egypt.

2 Department, of Pharmacology, Faculty of Veterinary Medicine, Cairo University, Cairo, Egypt.

3 Department of Forensic Medicine, Faculty of Veterinary Medicine, Matrouh University, Matrouh, Egypt.
\end{abstract}

Correspondence

Yasmin Abouelbaqa, Department of Pharmacology, Faculty of Veterinary Medicine, Matrouh University, Matrouh, Egypt.

Email: vet.yasmin.muhammed@gmail.com

Received: $11 / 1 / 2021$

Accepted: $24 / 1 / 2021$

\section{ABSTRACT}

Natural betaine is a natural amino acid derivative (trimethylglycine) that is found in beet molasses and their residues. Phytochemical, pharmacological, and toxicological properties of betaine have been tested in this study. Ninety mice were used to study betaine toxicity and analgesic activity. Fifty mice were distributed into five groups of ten mice to be used in the toxicological study while forty animals were distributed into four groups of ten mice each during the analgesic study. Forty-eight rats were used to investigate the anti-inflammatory and antipyretic activities of betaine. Rats were distributed into four groups of six animals each during both experiments. The anti-inflammatory (carrageenaninduced paw edema), antipyretic (Brewer's yeast-induced pyrexia), and analgesic (chemical and thermal-induced pain) actions of betaine have been studied. The results indicated that natural betaine has an oral LD50 of $5800 \mathrm{mg} \backslash \mathrm{kg}$. Rats treated with betaine (100 or $200 \mathrm{mg} / \mathrm{kg}$ orally) exhibited a significant reduction in rats' paws thickness compared to the control group. The hyperthermia model and the analgesic model demonstrated good antipyretic and analgesic actions of betaine compared to the standard groups. These findings suggest that oral administration of natural betaine had significant anti-inflammatory and antipyretic activities in rats in addition to antinociceptive activity in mice.

Keywords: Natural betaine - Anti-inflammatory- Antinociceptive - Antipyretic-LD50.

the required level, they result in unfavorable outcomes such as malignant hyperthermia or autoimmune diseases. Drugs with anti-inflammatory action also have antipyretic action for instance, e.g. nonsteroidal anti-inflammatory drugs (NSAIDs) (Begum et al., 2011). The therapeutic benefits of NSAIDs have been found as a result of COX-2 inhibition, while suppression of COX-1 induces digestive and urinary side effects. Gastrointestinal (GI) toxicity is by far the most common symptom of NSAIDs. Inhibition of COX-1 enzymes suppresses the synthesis of cytoprotective prostaglandins such as prostaglandin PGE2 and PGI2, which resulted in GI toxicity (Suleyman et al., 2007). Searching for safer natural therapeutic alternatives with potential antipyretic and antiinflammatory activities such as betaine recently received attention as the present NSAIDs have been associated with various side effects on the body organs. Betaine is a fundamental constituent of the homocysteine-methionine cycle and is produced by the oxidation of choline. It was 
detected for the first time in sugar beets (Beta vulgaris) and also has been identified in different plants, animals, and several microorganisms. Betaine has a critical role in cell signaling, cell membrane integrity besides the formation of neurotransmitters (Kim et al., 2014). Food consumption of choline and betaine has been recorded to have an antiinflammatory impact. Interleukin 6 (IL- 6), TNF- $\alpha$, COX-2, and iNOS expression significantly decrease in the tumors of mouse colon following dietary intake of betaine at doses of 1,5 , and $10 \mathrm{mg} / \mathrm{kg}$ for 16 weeks. Betaine has been known to have antioxidant activity, which increases the levels of superoxide dismutase (SOD) and glutathione peroxidase (GPx) against the production of reactive oxygen species (ROS) while decreasing malondialdehyde (MDA) levels (Hassanpour et al., 2020). Therefore, betaine therapy is beneficial against conditions associated with oxidative stress e.g., atherosclerosis, renal, and hepatic disorders (Evran et al., 2018). So, in this study, natural betaine has been investigated for its potential antipyretic, anti-inflammatory activity in a rat model as well as anti-nociceptive in a mice model.

\section{MATERIALS AND METHODS}

Natural Betaine: Natural betaine, $40 \%$ solution was obtained as a patent preparation as oral water soluble solution produced by Agrana, AUSTRIA under trade name ActiBeet ${ }^{\circ}$.It was analyzed by Pharma Swede-Egypt and betaine HCL was considered as a refence. Ethical approval: The experimental design of the present study was ethically approved by the Ethics Review Committee of the Faculty of Veterinary Medicine, Alexandria University, Egypt (Approval No. 0106321). Animals:

1-Mice: Ninety mature male mice weighing 20-25 gm were used to study betaine toxicity and analgesic activity. The mice were obtained from the animal house, Faculty of Science, Alexandria University. Fifty mice were distributed into five groups of ten mice each to be used in the toxicological study while forty animals were distributed into four groups of ten mice each during the analgesic study of betaine. 2-Rats: Forty-eight mature male Wistar albino rats weighing 190-200 gm were used to investigate the anti-inflammatory and antipyretic activities of betaine. The rats were obtained from the animal house, Faculty of Science, Alexandria University. Rats were randomly distributed into four groups of six animals each during both experiments. Animals were kept at $23 \pm 2^{\circ} \mathrm{C}$ in plastic cages with metal mesh leds and were exposed to $12 \mathrm{hr}$. dark/light cycle. All experimental animals (mice and rats) were acclimatized for two weeks before the starting of the experiment. During this period, the animals were kept in plastic cages with food and water ad libitum. Determination of LD50: LD50 of betaine was performed on fifty mice (20-25 gm) using the method stated by Kerber (1941). Five groups of 10 mice each, one group used as a control, and the other four groups were treated with betaine on ascending doses $(40,80,120,160$, and $200 \mathrm{mg} / 20 \mathrm{~g}$ b.wt).
Animals were observed for 48 hours to record toxic symptoms, rate of mortality, and postmortem changes within each group. LD50 of betaine was determined as the following formula:

$$
\mathrm{LD}_{50}=\mathrm{Dm}-\frac{\Sigma(\mathrm{zxd})}{\mathrm{n}}
$$

\section{Where:}

$\mathrm{Dm}=$ the highest dosage to kill the animals.

$\mathrm{z}=$ average number of dead animals between two successive groups.

$\mathrm{d}=$ the constant value between two successive doses.

$\mathrm{n} \quad=$ number of animals per group.

$\Sigma=$ the sum of $(a \times b)$.

\section{B-Pharmacological studies:}

\section{1-Anti-inflammatory effect:}

Male Wister rats of $150-200$ gm b.wt were randomized into four groups of six animals. Group I was treated as control with induced inflammation only, group II and group III received orally 100 and $200 \mathrm{mg} / \mathrm{kg}$ of natural betaine, respectively, whereas group IV was treated as a standard by the administration of diclofenac sodium $30 \mathrm{mg} / \mathrm{kg}$ b.wt orally.

Preinjection volume of paws was measured immediately before carrageenan injection. $0.1 \mathrm{ml}$ of $1 \%$ carrageenan solution dissolved in $0.9 \%$ saline was subcutaneously administered into the plantar surface of the left hind paw to induce edema or inflammation, thirty minutes before drug or betaine administration according to Winter et al. (1962). Vernier caliper was used to measure each rat paw thickness in $\mathrm{mm}$ to assess the inflammatory response caused by carrageenan after 1,3 , and 6 hours. The point of measurement was premarked with a permanent pen to be used as a reference in the following measurements.

\section{2- Antipyretic effect:}

Male Wister rats of $150-200$ gm b.wt were randomized into four groups of six animals. Rectal temperature for each rat was measured then all animals were injected subcutaneously into the dorsum region by $12.5 \%$ Brewer's yeast suspension in normal saline to induce hyperthermia. Rectal temperature was measured 17 hours later using a digital thermometer for all animals to act as a baseline of high body temperature, which was compared to the antipyretic effect of betaine (animals with increased rectal temperature about 0.3-0.5 ㅇ C have been chosen).

Group I was treated as control with induced pyrexia only, group II and group III were administered orally 100 and 200 $\mathrm{mg} / \mathrm{kg}$ of natural betaine, respectively. Group IV served as a standard by oral administration of paracetamol $50 \mathrm{mg} / \mathrm{kg}$ b.wt. Rectal temperature was measured at 1, 3, and 6 hours after administration of betaine or medication following the method described by (Teotino et al., 1963).

\section{3-Analgesic effect: \\ Hot plate test:}

In the first experiment, the hot plate test was used to estimate the anti-nociceptive activity of betaine in mice as stated by Janssen and Jageneau (1957) and adjusted by (Jacob and Bosovski, 1961). Forty male mice of 20-25 gm b.wt were distributed into four groups of ten mice each. Group I served 
as an untreated control group, while Group II and III were administered oral betaine at a concentration of 100 and 200 $\mathrm{mg} / \mathrm{kg}$ b.wt, respectively, whereas group IV was administered oral paracetamol at a dosage of $50 \mathrm{mg} / \mathrm{kg}$.

This method depends on a thermostatically controlled water bath with a temperature of $56 \pm 0.5^{\circ} \mathrm{C}$ and a 2-liter beaker placed in a water bath to prepare the hot plate. Thirty minutes after the treatment has been orally administered, each animal was inserted into the beaker until the animal licked its paw or jumped. The reaction time of analgesic activity is calculated by the time passed until the mouse licked its paw or jumped. The reaction time in all groups was estimated at 1,3 , and 6 hours post oral administration of betaine in comparison to the control non-treated group and the standard group.

\section{Writhing test:}

In the second experiment, abdominal constrictions induced by acetic acid (writhing activity) were determined in mice as described by Collier et al. (1968). Writhing is defined as an exaggerated extension of the abdomen in conjunction with hind limbs extension induced by acetic acid (Hassanpour et al., 2020). Forty male mice of 20-25 gm b.wt were distributed into four groups of ten mice each. Group I was treated as the untreated control group, while group II and III were administered oral betaine at doses of 100 and $200 \mathrm{mg} / \mathrm{kg}$ b.wt, respectively, while group IV was administered paracetamol orally at $50 \mathrm{mg} / \mathrm{kg}$. Within 30 minutes, animals received $0.7 \%$ of the aqueous acetic acid solution by intraperitoneal injection (10 $\mathrm{ml} \backslash \mathrm{kg}$ b.wt), and then the mice were housed in transparent cages to be observed. Writhes number in each treated group was recorded for 20 minutes after the injection of the glacial acetic acid solution and compared to the writhes number of the non-treated control group. The number of abdominal stretching (writhes) was counted and the percentage of protection was determined as follows:

Percentage of protection $=\frac{\text { Control mean }- \text { treated mean }}{\text { Control } \text { mean }} \times 100$

\section{C- Statistical analysis:}

The results were expressed as mean \pm SE of studied groups using the analysis of variance test (one way ANOVA) followed by Bonferroni test. All analysis was performed by statistical package for the social science software (SPSS Inc., Chicago, IL). Values of $\mathrm{P}<0.05$ were considered significant.

\section{RESULTS}

AToxicological studies:

LD50:

The obtained result revealed that oral administration of natural betaine at a dose up to $2000 \mathrm{mg} / \mathrm{kg} \mathrm{b.wt} \mathrm{did} \mathrm{not}$ induce any mortalities or signs of toxicity. Soft stool was found in groups receiving various betaine doses. Signs of acute toxicity e.g., diarrhea, hematuria, lethargy, uncoordinated muscular movements, respiratory failure, and mortalities occurred following betaine administration at doses from 4000 up to $10000 \mathrm{mg} / \mathrm{kg}$. After calculation, LD50 of natural betaine given orally was estimated to be $5800 \mathrm{mg} / \mathrm{kg}$.

\section{B- Pharmacological studies:}

1- Anti-inflammatory activity:

The natural betaine was tested for its anti-inflammatory effect by induction of rat paw edema using carrageenan suspension and the results were compared with the control data in Table (1) and graph (1). Injection of Carrageenan subcutaneously into the plantar area in rats paw in all animals produced a rapid substantial increase in the thickness of each paw. After 1, 3, and 6 hours, rats' paw thickness was significantly $(P \leq 0.05)$ affected after treatment with natural betaine $(200 \mathrm{mg} / \mathrm{kg}$, orally) and diclofenac sodium $(30 \mathrm{mg} / \mathrm{kg}$ ) when compared with the control group. Meanwhile, the group that received $100 \mathrm{mg} / \mathrm{Kg}$ natural betaine was significantly $(P \leq 0.05)$ affected after 3 and $6 \mathrm{hr}$. only when compared with the control group. Six hours after carrageenan injections, the doses of betaine $100 \mathrm{mg} / \mathrm{kg}$ and $200 \mathrm{mg} / \mathrm{kg}$ reduced paw edema to $(4.47 \pm 0.26)$ and $(4.37 \pm 0.21)$ respectively, compared to the non-treated group (5.31 \pm 0.11 ). At this time, diclofenac sodium also reduced the paw to $4.6 \pm 0.24$.

Table (1): The effect of natural betaine on Carrageenan induced edema $(n=6)$.

\begin{tabular}{|c|c|c|c|c|c|}
\hline \multirow[t]{2}{*}{ Groups } & \multirow[t]{2}{*}{$\begin{array}{l}\text { Dose } \\
\text { (mg/kg } \\
\text { b.wt) }\end{array}$} & \multirow{2}{*}{$\begin{array}{l}\text { Thicknes } \\
\text { s before } \\
\text { inductio } \\
n\end{array}$} & & & \\
\hline & & & $1 \mathrm{hr}$ & $3 \mathrm{hr}$ & $6 \mathrm{hr}$ \\
\hline $\begin{array}{l}\text { Control } \\
\text { non } \\
\text { treated }\end{array}$ & - & $\begin{array}{l}3.92 \\
\pm 0.068^{\mathrm{a}}\end{array}$ & $\begin{array}{l}5.5 \\
\pm 0.19 \text { a }\end{array}$ & $\begin{array}{l}5.35 \\
\pm 0.15^{\text {a }}\end{array}$ & $\begin{array}{l}5.31 \\
\pm 0.11^{\mathrm{a}}\end{array}$ \\
\hline \multirow[t]{2}{*}{$\begin{array}{l}\text { Natural } \\
\text { Betaine }\end{array}$} & 100 & $\begin{array}{c}3.73 \\
\pm 0.13^{a}\end{array}$ & $\begin{array}{l}5.3 \\
\pm 0.18^{a}\end{array}$ & $\begin{array}{l}4.72 \\
\pm 0.13^{b}\end{array}$ & $\begin{array}{l}4.47 \\
\pm 0.26\end{array}$ \\
\hline & 200 & $\begin{array}{l}3.85 \\
\pm 0.095 \text { a }\end{array}$ & $\begin{array}{l}5.0 \\
\pm 0.19 b\end{array}$ & $\begin{array}{l}4.48 \\
\pm 0.17 \mathrm{~b}\end{array}$ & $\begin{array}{l}4.37 \\
\pm 0.21^{b}\end{array}$ \\
\hline $\begin{array}{l}\text { Standard } \\
\text { (diclofen } \\
\text { ac } \\
\text { sodium) }\end{array}$ & 30 & $\begin{array}{l}3.83 \\
\pm 0.094 \text { a }\end{array}$ & $\begin{array}{l}4.53 \\
\pm 0.52^{b}\end{array}$ & $\begin{array}{l}4.97 \\
\pm 0.12 \mathrm{~b}\end{array}$ & $\begin{array}{l}4.6 \\
\pm 0.24 b\end{array}$ \\
\hline
\end{tabular}

Means with different letters $(a, b)$ in the same column are significantly different at $a P$-value $\leq 0.05$ (Bonferroni test).

Graph 1: Distribution of anti-inflammatory activity of betaine extract with rat paw edema induced by Carrageenan in comparison with the standard Diclofenac sodium.

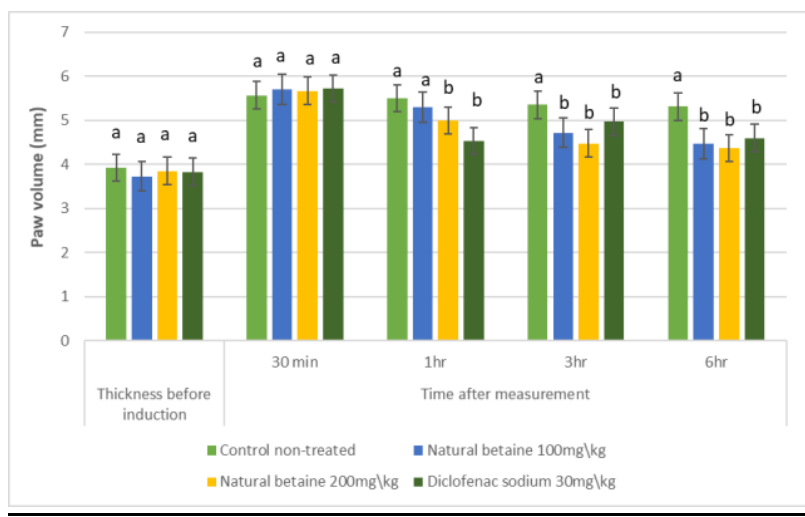




\section{2-Antipyretic Activity:}

The natural betaine effect on rats' rectal temperature is shown in Table (2) and Graph (2). Rectal temperature of rats highly increased $17 \mathrm{hr}$. post subcutaneous injection of brewer's yeast suspension. Treatment with natural betaine in doses of 100 or $200 \mathrm{mg} / \mathrm{kg}$ resulted in a significant $(P \leq 0.05)$ reduction in rectal body temperature of rats. At doses of $(100,200 \mathrm{mg} / \mathrm{kg})$ betaine caused a dose-dependent antipyretic effect, generating marked antipyretic activity in hyperthermic rats induced by brewer's yeast.

Table (2): The Effect of natural betaine on Brewer yeast induced pyrexia on rats $(n=6)$ :

\begin{tabular}{|c|c|c|c|c|c|c|}
\hline \multirow[t]{2}{*}{ Groups } & \multirow{2}{*}{$\begin{array}{l}\text { Dose } \\
\text { (mg/ } \\
\mathrm{kg}) \\
\text { b.wt }\end{array}$} & \multirow{2}{*}{$\begin{array}{l}\text { Initial } \\
\text { body } \\
\text { temper } \\
\text { ature }\end{array}$} & \multirow{2}{*}{$\begin{array}{l}\text { After } \\
17 \\
\text { hours } \\
\text { of } \\
\text { yeast }\end{array}$} & \multicolumn{3}{|c|}{$\begin{array}{l}\text { Time } \\
\text { Of } \\
\text { measurement }\end{array}$} \\
\hline & & & & $1 \mathrm{hr}$ & $3 \mathrm{hr}$ & $6 \mathrm{hr}$ \\
\hline $\begin{array}{l}\text { Control } \\
\text { Non } \\
\text { treated }\end{array}$ & 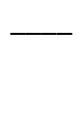 & $\begin{array}{l}37.18 \pm \\
0.88^{a}\end{array}$ & $\begin{array}{l}39.52 \pm \\
0.33^{\mathrm{a}}\end{array}$ & $\begin{array}{l}39.13 \pm \\
0.53^{a}\end{array}$ & $\begin{array}{l}38.82 \pm \\
0.81^{a}\end{array}$ & $\begin{array}{l}38.67 \pm \\
0.59^{a}\end{array}$ \\
\hline \multirow[t]{2}{*}{$\begin{array}{l}\text { Natural } \\
\text { Betaine }\end{array}$} & 100 & $\begin{array}{l}37.38 \pm \\
1.42^{\mathrm{a}}\end{array}$ & $\begin{array}{l}39.14 \pm \\
0.65^{a}\end{array}$ & $\begin{array}{l}37.1 \pm \\
0.37^{b}\end{array}$ & $\begin{array}{l}37.23 \pm \\
0.23^{b}\end{array}$ & $\begin{array}{l}36.9 \pm \\
0.41^{c}\end{array}$ \\
\hline & 200 & $\begin{array}{l}37.56 \pm \\
0.68^{\mathrm{a}}\end{array}$ & $\begin{array}{l}39.26 \pm \\
0.61^{\mathrm{a}}\end{array}$ & $\begin{array}{l}37.7 \pm \\
0.33^{b}\end{array}$ & $\begin{array}{l}36.47 \pm \\
0.094^{c}\end{array}$ & $\begin{array}{l}36.73 \pm \\
0.12^{c}\end{array}$ \\
\hline $\begin{array}{l}\text { Standard } \\
\text { (paraceta } \\
\text { mol) }\end{array}$ & 50 & $\begin{array}{l}37.20 \pm \\
0.93 \text { a }\end{array}$ & $\begin{array}{l}39.72 \pm \\
0.58^{a}\end{array}$ & $\begin{array}{l}36.53 \pm \\
0.18^{c}\end{array}$ & $\begin{array}{l}37.27 \pm \\
0.35^{b}\end{array}$ & $\begin{array}{l}37.63 \pm \\
0.15^{b}\end{array}$ \\
\hline
\end{tabular}

Means with different letters $(a, b, c)$ in the same column are significantly different at a $P$-value $\leq 0.05$.

Graph 2. Effect of different concentrations of betaine on yeast-induced pyrexia in rats:

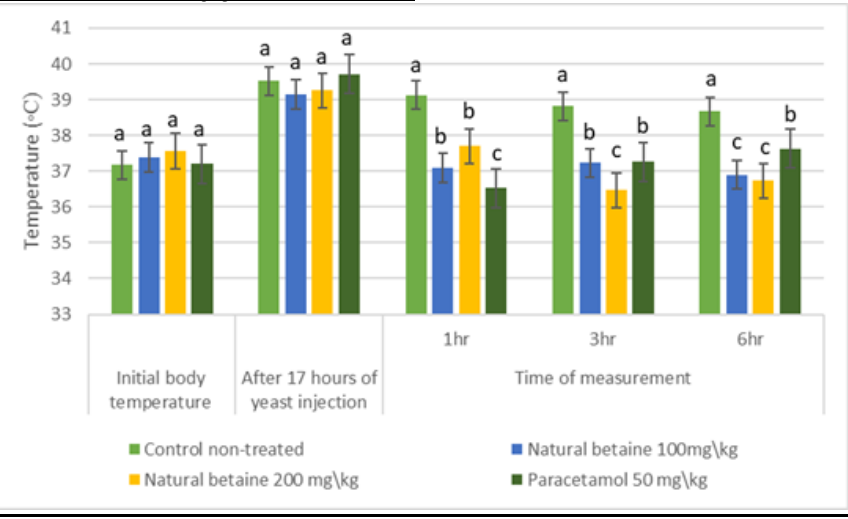

\section{3-Analgesic effect:}

\section{Hot plate method:}

The effect of natural betaine on the hot plate test is presented in Table (3) and graph (3). Natural betaine was administered orally at various dosage levels and caused significantly prolonged reaction time in the hot plate test. Dosages of natural betaine (100 and $200 \mathrm{mg} / \mathrm{kg}$ ) produced its analgesic activity in 30 minutes post-administration until the study ended. The highest reaction time $16.67 \pm 1.86$ was noticed at a dosage of $200 \mathrm{mg} / \mathrm{kg}$, at 6 hours after treatment with betaine compared to $6.00 \pm 1.26$ of the control nontreated group.
Table (3): The effect of natural betaine extract on the hot plate reaction time in mice $(n=10)$ :

\begin{tabular}{|c|c|c|c|c|c|}
\hline \multirow[t]{2}{*}{ Groups } & \multirow{2}{*}{$\begin{array}{l}\text { Dosel } \\
\mathrm{mg} / \mathrm{kg} \\
\text { b.wt }\end{array}$} & \multirow{2}{*}{$\begin{array}{l}\text { Before } \\
\text { treat } \\
\text { ment }\end{array}$} & \multicolumn{3}{|c|}{ Time of measurement } \\
\hline & & & $1 \mathrm{hr}$ & $3 \mathrm{hr}$ & $6 \mathrm{hr}$ \\
\hline $\begin{array}{l}\text { Control } \\
\text { Non } \\
\text { treated }\end{array}$ & 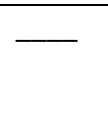 & $\begin{array}{l}9.05 \\
\pm 1.23 \mathrm{a}\end{array}$ & $\begin{array}{l}7.9 \\
\pm .83 \mathrm{~b}\end{array}$ & $\begin{array}{l}7.5 \pm \\
0.74 b\end{array}$ & $6.51 \pm 0.63 c$ \\
\hline \multirow[t]{2}{*}{$\begin{array}{l}\text { Natural } \\
\text { Betaine }\end{array}$} & 100 & $\begin{array}{l}8.4 \pm \\
0.54 a\end{array}$ & $\begin{array}{l}13.50 \pm \\
1.51 \mathrm{a}\end{array}$ & $\begin{array}{l}13.50 \\
\pm 1.87 \mathrm{~b}\end{array}$ & $13.00 \pm 3.35 b$ \\
\hline & 200 & $\begin{array}{l}8.33 \\
\pm 0.45 a\end{array}$ & $\begin{array}{l}15.17 \pm \\
1.49 a\end{array}$ & $\begin{array}{l}16.50 \\
\pm 1.88 \mathrm{a}\end{array}$ & $16.67 \pm 1.86 a$ \\
\hline $\begin{array}{l}\text { Standard } \\
\text { (paracet } \\
\text { amol) }\end{array}$ & 50 & $\begin{array}{l}7.33 \\
\pm 0.63 \mathrm{a}\end{array}$ & $\begin{array}{l}17.67 \pm \\
1.75 a\end{array}$ & $\begin{array}{l}16.50 \\
\pm 1.87 \mathrm{a}\end{array}$ & $15.71 \pm 1.67 a$ \\
\hline
\end{tabular}

Means with different letters $(a, b, c)$ in the same column are significantly different at a $P$-value $\leq 0.05$.

Graph 3. Effect of betaine on reaction time in the hot-plate test in mice

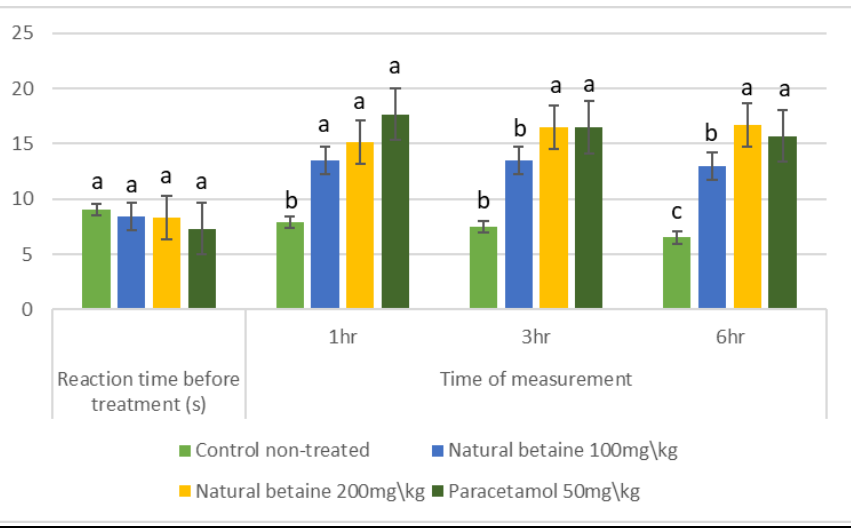

\section{Writhing method:}

Writhing test, which was induced by acetic acid was used to study the anti-nociceptive action of natural betaine as shown in Table (4) and graph (4). Natural betaine was found to have dose-dependent analgesic activity. Oral dosage of betaine $(200 \mathrm{mg} \backslash \mathrm{kg}$ ) decreased writhes number with an inhibition percentage of 63.07 compared to the standard group treated with paracetamol $(50 \mathrm{mg} / \mathrm{kg})$ with an inhibition percentage of $64.67 \%$. Doses of 100 and 200 $\mathrm{mg} / \mathrm{kg}$ of oral betaine extract significantly $(P \leq 0.05)$ decreased acetic acid-induced abdominal contractions to $12.5 \pm 0.79$ and $10.23 \pm 0.41$, respectively, compared to the control group $(27.7 \pm 1.64)$.

Table (4): The effect of natural betaine on an acetic acidinduced writhing in mice $(n=10)$ : 


\begin{tabular}{|l|l|l|l|}
\hline Groups & $\begin{array}{l}\text { Dose in } \\
\mathrm{mg} / \mathrm{kg} \\
\text { body } \\
\text { weight }\end{array}$ & $\begin{array}{l}\text { No. of } \\
\text { writhes/20 } \\
\text { minutes }\end{array}$ & $\begin{array}{l}\text { Inhibition } \\
(\%)\end{array}$ \\
\hline $\begin{array}{l}\text { Control non } \\
\text { treated }\end{array}$ & - & $27.7 \pm 1.64$ & 0 \\
\hline $\begin{array}{l}\text { Natural } \\
\text { Betaine }\end{array}$ & 100 & $12.5 \pm 0.79$ & 54.87 \\
\cline { 2 - 4 } & 200 & $10.23 \pm 0.41$ & 63.07 \\
\hline $\begin{array}{l}\text { Standard } \\
\text { Paracetamol }\end{array}$ & 50 & $9.8 \pm 0.57$ & 64.62 \\
\hline
\end{tabular}

Graph (4): Percent of inhibition of pain response in writhing test induced by acetic acid in mice $(n=10)$ :

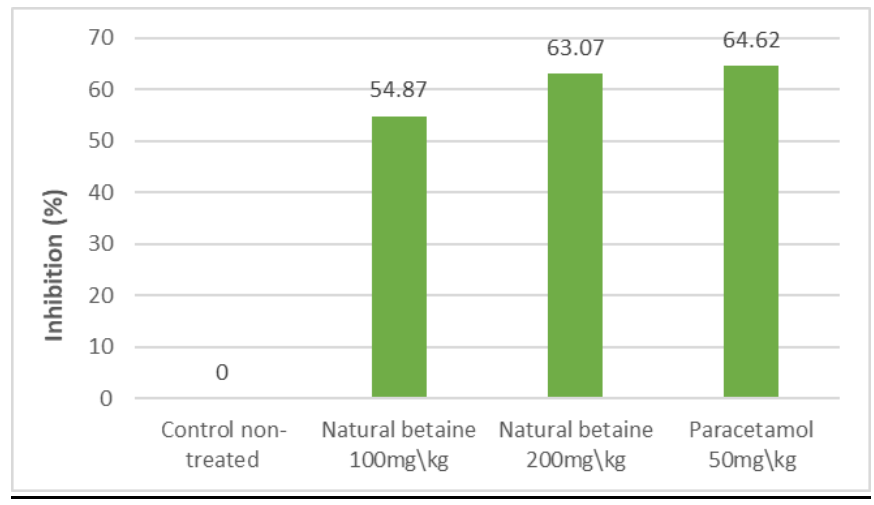

\section{DISCUSSION}

This study investigated the potential antipyretic, antiinflammatory, and analgesic activities of natural betaine. Apparently, betaine demonstrated no mortalities at the maximum oral dose of $2000 \mathrm{mg} / \mathrm{kg} \mathrm{b.wt}$ whereas the oral LD50 of natural betaine in mice was more than $5000 \mathrm{mg} / \mathrm{kg}$ b.wt. This means that, natural betaine is very safe and nontoxic compound indicated by a large value of LD50. In this respect, Buck et al., (1976) reported that substances with LD50 lower than $10 \mathrm{mg} \backslash \mathrm{kg}$ b.wt are considered extremely toxic while others with LD50 higher than $50 \mathrm{mg} \backslash \mathrm{kg}$ are considered non-toxic.

The present study was also designed to assess the antiinflammatory action of betaine using the Carrageenaninduced edema in rats paw. Edema induction in the paw of rats by various agents such as carrageenan suspension is a two-phase reaction in which the primary stage is initiated by histamine, serotonin, and kinins, while the secondary stage is induced by prostaglandins (arachidonic acid metabolism product by cyclo-oxygenase enzyme) and reactive oxygen species (ROS) formation (Chen, 1993 and Panthong, 2004).

At both 100 and $200 \mathrm{mg} / \mathrm{kg}$, natural betaine exhibited a significant decrease in paw edema in rats after 1,3 , and 6 hours when compared to the standard group of diclofenac sodium. This result was found to be compatible with (Adhikari et al., 2017) who found that beet roots extract at $100 \mathrm{mg} \backslash \mathrm{kg}$, $200 \mathrm{mg} \backslash \mathrm{kg}$, and $400 \mathrm{mg} \backslash \mathrm{kg}$ inhibited raw paw edema induced by Carrageenan by $25.83 \%, 33.75 \%$ and $50 \%$, respectively after four hours of treatment.
Reduction of paw edema at 1 and 6 hours by natural betaine is suggested to be contributed to its antagonistic effect on primary-stage compounds (histamine, serotonin, and kinins) or its antagonism on secondary-stage compounds (prostaglandins) or its formation by suppression of the COX enzyme followed by a consequent decrease in prostaglandins synthesis and may be contributed to the suppression of reactive oxygen species production by phagocytes (secondary phase mediator) inducing tissue damage after reaching the inflammatory site (Cross et al., 1987; Winrow et al., 1993; Parke and Sapota, 1996).

It is also suggested that betaine has a protective effect during cellular stress and also takes part in different biological processes. In vitro, studies have indicated that betaine has a significant anti-inflammatory effect. Betaine prevents the release of nitric oxide from activated microglia. In vivo, previous studies showed that betaine therapy in aged kidneys was found to suppress the activity of NF-kB and other related genes expression as VCAM-1 (vascular cell adhesion molecule-1), TNF- $\alpha$, and ICAM-1 (intracellular cell adhesion molecule-1), iNOS (inducible nitric oxide synthase) and COX-2 (cyclooxygenase-2) (Go et al., 2005; and Adhikari et al., 2017).

Several genes are involved in the pathogenesis of inflammation are controlled by the NF- B (transcription factor nuclear factor- $\mathrm{kB}$ ) signaling pathway. The genes involved in the inflammatory process include the TNF- $\alpha$ (tumor necrosis factor-alpha), pro-inflammatory cytokines, IL-23 (interleukin 23), and IL-1 $\beta$ (interleukin 1 beta). NF-k $B$ is activated chronically in several diseases of inflammatory origin (Monaco et al., 2004; Aravilli et al., 2017). So, the nuclear factor-kB pathway has known to be a very important candidate for the treatment of inflammation. Betaine has been reported by several researchers to suppress the activity of $\mathrm{NF}_{-\mathrm{k}} \mathrm{B}$ and different genes involved in the inflammatory process (Go et al., 2005; Lee et al., 2013).

Regarding the antipyretic activity of natural betaine, the current result indicates that betaine at both 100 and 200 $\mathrm{mg} / \mathrm{kg}$ doses has significant antipyretic activity on high body temperature induced by Brewer's yeast in rats in comparison with the effect of paracetamol . XU et al. (1986) also stated that oral administration of betaine was found to have an antipyretic activity in vaccinated hyperthermic rabbits and had no effect on the temperature of normal healthy animals.

Spacer and Breder (1994) stated that pyrexia is induced by the release of pro-inflammatory cytokines as interleukin $\alpha$, $\beta$, and TNF-alpha followed by an increase of PGE2 formation near the preoptic-anterior hypothalamus, which subsequently elevates body temperature. In addition, plants exhibiting antipyretic activity have been recorded to also have analgesic effects (Dewan et al., 2000). The antipyretic activity of betaine is suggested to be attributable to the counteracting of prostaglandins on the anterior hypothalamus. 
Concerning the analgesic activity of natural betaine, this study showed that natural betaine has both central and peripheral analgesic efficacy at both doses $100-200 \mathrm{mg} / \mathrm{kg}$. Formalin \acetic acid-induced writhing tests are the animal model of pain studies designed to assess the anti-nociceptive activities of various substances. Intraperitoneal injection of acetic acid stimulates the formation of pro-inflammatory cytokines and triggers the peripheral pain receptors on sensory nerve fibers which causes pain and hyperalgesia (Hassanpour et al., 2020). In the writhing test, the obtained results showed that doses of 100 and $200 \mathrm{mg} / \mathrm{kg}$ of oral betaine significantly $(P \leq 0.05)$ inhibited acetic acid-induced abdominal contractions by $54.87 \%$ and $63.07 \%$, respectively when compared to the standard group (64.62\%).This result was supported by the findings observed by Hassanpour et al.(2020) who found that betaine administration significantly reduced the writhing test pain response by $59.37 \%$ when compared to the control group.

Since the effect of natural betaine was found to be $63.07 \%$ compared to standard paracetamol $64.67 \%$, it is suggested that natural betaine acts by a similar mechanism to NSAIDs through inhibition of cyclooxygenase or lipoxygenase pathway which block substance $P$ function that stimulates pain in nerve endings. Eun et al.,(2007) stated that cellular treatment of betaine inhibited activation of NF-kB which controls the action of numerous genes, such as TNF, cyclooxygenase-2 (COX- 2), inducible NO synthase, subsequently followed by suppressed expression of cox- 2 and TNF.

The central effect of betaine was identified using the hot plate test, by calculating the reaction time until the mouse jumped or licked its paws. It appears that betaine has a dose-dependent mechanism of action. The antiinflammatory and anti-nociceptive effect of natural betaine may be associated with its bioactive constituents as alkaloids. In this respect Blunden et al., (1981) reported that betaines are known as QACs, which are quaternary ammonium substances with a completely methylated nitrogen atom that has a permanent positive charge. Betaine glycine is one of the best-known betaines and has a widespread distribution in plants. Early analysis of betaines relied generally on ionexchange chromatography, paper chromatography, or TLC, with visualization of the separated compounds using Dragendorff's reagent (Grieve and Grattan, 1983).

\section{CONCLUSION}

From previous findings, it was concluded that natural betaine has anti-inflammatory, analgesic, and antipyretic activities. This provides a different approach to the treatment of pyrexia, inflammation, and pain. These activities confirm the value of betaine in folk medicine for treating serious inflammatory diseases. The study also suggests additional research for the isolation of phytochemicals related to each action.

\section{CONFLICT OF INTEREST}

The authors declare no conflicts of interest related to this report.

\section{REFERENCES}

1. Adhikari, A., Saha, A., Indu, R., Sur, T. K. and Das, A. K. (2017). Evaluation of anti-inflammatory effect of beetroot extract in animal models. International Journal of Basic \& Clinical Pharmacology, 6, 2853-8.

2. Aravilli, R.K., Vikram, S.L., Kohila, V. (2017). Phytochemicals as potential antidotes for targeting NF-_B in rheumatoid arthritis.3 Biotech. 7(4): 253. 10.1007/s13205-017-0888-1.

3. Begum, T. N., Ilyas, M. H. M. , Anand, A. V. (2011). Antipyretic activity of azima tetracantha in experimental animals. International Journal of Current Biomedical and Pharmaceutical Research, 1(2): 41-44.

4. Blunden, G., El Barouni, M. M., Gordon, S.I., Mclean, W.F.H., Rogers, D.J. (1981). Extraction, purification and characterisation of Dragendorff-positive compounds from some marine algae. Botanica marina, 24: 451-456.

5. Buck, W.B, Osweiter, G.D and Van Gelder, A.G. (1976). Clinical and diagnostic veterinary toxicology 2nd ed. Kendall/Hunt publishing company, Dubuque, lowa, 69-75.

6. Chattopadhyay, D., Arunachalam, G., Ghosh, L., Rajendran, K., Mandal, A. B. , Bhattacharya, S. K. (2005) .Antipyretic activity of Alstonia macrophylla Wall ex A. DC: An ethnomedicine of Andaman Islands. Journal of Pharmacy and Pharmaceutical Sciences, 8(3): 558-564.

7. Chen, Z., Silva, H. , Klessig, D. F.(1993). Active oxygen species in the induction of plant systemic acquired resistance by salicylic acid. Science, 262(5141): 1883-1886.

8. Collier, H.D.J, Dinnin, L.C., Johnson, C.A. , Schneider, C. (1968). The abdominal response and its suppression by analgesic drugs in the mouse. British journal of pharmacology and chemotherapy, 32,295310.

9. Cross, C. E., Halliwell, B., Borish, E. T., Pryor, W. A., Ames, B. N., Saul, R. L., Harman, D. (1987).Oxygen radicals and human disease. Annals of internal medicine, 107(4): 526-545.

10. Dewan, S. O. N. E. E. R. A., Kumar, S. U. R. E. S. H. , Kumar, V. L. (2000). Antipyretic effect of latex of Calotropis procera. Indian journal of Pharmacology, 32(3), 252-252.

11. Eun, K. G. , Kyung, J. J. , Ji, M. K. , Lim, H. , Hyeang, K. L. , Byung, P. Y. , Hae, Y. C. (2007). Betaine modulates age-related NF-KB by thiol-enhancing action. Biological and Pharmaceutical Bulletin, 30(12): 2244-2249.

12. Evran, B., Aydın, A. F., Uğuralp, B., Sar, M., DoğruAbbasoğlu, S. , Uysal, M. (2018). Betaine treatment 
decreased serum glucose and lipid levels, hepatic and renal oxidative stress in streptozotocin-induced diabetic rats. Turkish Journal of Biochemistry, 43(4):343-351.

13. Go, E.K., Jung, K.J., Kim, J.Y., Yu, B.P., Chung, H.Y. (2005). Betaine suppresses proinflam-matory signaling during aging: the involvement of nuclear factor-kappaB via nuclear factor-inducing kinase/lkappaB kinase and mitogen-activated protein kinases. The Journals of Gerontology Series A: Biological Sciences and Medical Sciences, 60(10): 1252.

14. Grieve, C. M, Grattan, S. (1983). Rapid assay for determination of water soluble quaternary ammonium compounds, Plant and Soil, 70(2): 303307.

15. Hassanpour, S., Rezaei, H. , Razavi, S. M. (2020). Antinociceptive and antioxidant activity of betaine on formalin- and writhing tests induced pain in mice. Behavioural Brain Research, 390 (May): 112699. 10.1016/j.bbr.2020.112699.

16. Jacob, S. , Bosovski, M. (1961). "Screening methods in pharmacology". Academic press INC, New York and London, P.104.

17. Janssen, P.A. , Jageneau, A. (1957).A new series of potent analgesics :Part I .Chemical structre and pharmacological activity. Journal of Pharmacy and Pharmacology, 90: 381.

18. Kerber, G. (1941). Pharmakologische Methoden Zur Auffindung Von Arzneimitten und Gifter und Analyse ihrer Wirkungsweise Vor. Dr. Med. Leopold Ther.Wissenschaftliche verlage Gerlarge Gesse Gesellschaft.M.B.H.

19. Kim, D. H., Sung, B. ,Kang, Y. J., Jang, J. Y. , Hwang, S. Y. , Lee, Y. , Kim, M. , Im, E. , Yoon, J. H. , Kim, C. M. ,Chung, H. Y. , Kim, N. D. (2014). Anti-inflammatory effects of betaine on AOM/DSS-induced colon tumorigenesis in ICR male mice. International Journal of Oncology, 45(3): 1250-1256.

20. Lee, E.K., Jang, E.J., Jung, K.J., Kim, D.H., Yu, B.P., Chung, H.Y. (2013). Betaine attenuates lysophosphatidylcholine-mediated adhesion molecules in aged rat aorta: modulation of the nuclear factor kappa B pathway. . Experimental gerontology, 48: 517-24.

21. Monaco, C., Andreakos, E., Kiriakidis, S., Mauri, C., Bicknell, C., Foxwell, B., ... \& Feldmann, M. (2004). Canonical pathway of nuclear factor $\mathrm{KB}$ activation selectively regulates proinflammatory and prothrombotic responses in human atherosclerosis. Proceedings of the National Academy of Sciences, 101(15), 5634-5639.

22. Panthong, A., Kanjanapothi, D., Taesotikul, T., Phankummoon, A., Panthong, K. , Reutrakul, V. (2004). Anti-inflammatory activity of methanolic extracts from Ventilago harmandiana Pierre. Journal of Ethnopharmacology, 91(2-3): 237-242.
23. Parke, D.V. , Sapota, A. (1996). Chemical toxicity and reactive oxygen species. International journal of occupational medicine and environmental health, 9: 331-40.

24. Raju, G. S., Moghal, M. M. R. , Hossain, M. S. , Hassan, M. M., Billah, M. M., Ahamed, S. K., Rana, S. M. M. (2014). Assessment of pharmacological activities of two medicinal plant of Bangladesh: Launaea sarmentosa and Aegialitis rotundifolia roxb in the management of pain, pyrexia and inflammation. Biological Research, 47(1): 1-11.

25. Snedecor, G.W. and Cochran, W. (1969). "Statistical Methods". 4 Ed. lowa State University Press, Ames., lowa, USA., pp: 91-95.

26. Spacer, C.B. , Breder, CD. (1994). The neurologic basis of fever. New England journal of medicine, 330: 1880-1886.

27. Suleyman, H., Demircan, B. , Karagoz, Y. (2007). Antiinflammatory and side effects of cyclo-oxygenase inhibitors. Pharmacological reports, 59(3): 247.

28. Teotino, U.M., Friz, L.P., Gandini, A., Bella, D.D. (1963) .Thioderivative of 2-3-dihydro-4H-1,3benzoxazin-4-one synthesis and pharmacological properties. Journal of Medicinal Chemistry , 6: 248250.

29. White, D.M. (1996). Mechanisms of prostaglandin E2-induced substance $P$ release from cultured sensory neurons. Neuroscience, 70 (2): 561-565.

30. Winrow, V. R., Winyard, P.G., Morris, C. J. , Blake, D. R. (1993). Free radicals in inflammation:second messangers and mediators of tissue destruction, British medical bulletin, 49:506-522.

31. Winter, C.A., Risley, E.A., Nuss, G. W. (1962). Carrageenan induced edema in hind paw of the rat as an assay for anti-inflammatory drugs. Proceedings of the society for experimental biology and medicine, 111: 544-547.

32. Xu, D. Y., Yang, D. L., Ding, Y. S., \& Deng, P. (1986). The Sedative, Antipyretic And Analgesic Effects Of Betaine Hydrochloride [J]. Acta Pharmaceutica Sinica, 1.

\section{Cite this Paper}

Abouelbaqa Y., El banna H., Eldakroury M., and Abdelhiee E. (2021). Antinociceptive, Antipyretic and Anti-inflammatory Activities of Natural Betaine MJVM., 1(1): 1-7.

About the Journal
Matrouh Journal of Veterinary Medicine (MJVM)
The official journal of the faculty of veterinary
medicine, Matrouh University, Egypt.
Publisher: Matrouh University, Egypt.
ISSN (Online): 2735-4903
ISSN (Print): $2735-458 X$
Indexed in EKB Database

